\title{
Scapania gracilis Lindb. (Hepaticae, Scapaniaceae), new to bryophyte flora of Turkey
}

\author{
Tülay Ezer ${ }^{1}$, Recep Kara ${ }^{1}$ \& Mevlüt Alataş² \\ ${ }^{1}$ Niğde University, Faculty of Science, Department of Biology, 51100 Niğde-Turkey \\ E-mail: tezer@nigde.edu.tr \\ ${ }^{2}$ Zonguldak Karaelmas University, Faculty of Science and Arts, Department of Biology, Zonguldak-Turkey
}

\begin{abstract}
Scapania gracilis Lindb. is a hygro- to mesophytic liverwort species which is reported for the first time from Turkey. The species is described from material collected from the north-west Anatolia (Sakarya) which has very warm summers and mild winters with high annual rainfall $(800-1000 \mathrm{~mm})$ in Marmara region and very humid conditions. Turkish plants are described and illustrated.
\end{abstract}

\section{INTRODUCTION}

The genus Scapania (Dumort.) Dumort. is the largest genus of leafy hepatic family Scapaniaceae. About 230 species have been described in the world, they are widespred mainly in temperate regions (Ben-Rong et al., 2007). According to the latest list of Turkish liverworts (Kürschner \& Erdağ, 2005; Özenoğlu Kiremit \& Keçeli, 2009) eleven taxa of the genus (S. aequiloba (Schwägr.) Dumort., S. aspera Bernet et M. Bernet, S. compacta (Roth) Dumort., S. curta (Mart.) Dumort., S. irrigua (Nees) Nees, S. paludosa (Müll. Frib.) Müll. Frib., S. nemorea (L.) Grolle, S. subalpina (Nees ex Lindenb.) Dumort., S. umbrosa (Schrad.) Dumort., S. undulata (L.) Dumort., S. verrucosa Heeg) have been recognized as occuring in Turkey.

In this study Scapania gracilis Lindb. is recorded for Turkey as twelfth species. Description and illustrations of the species further contribute to the liverwort flora of Turkey.

\section{MATERIAL AND RESULTS}

Scapania gracilis Lindberg, Morgonbladet (Helsinki) 1873(286): 2. 1873.

Description of the Turkish specimens: plants medium size to robust, yellowish brown or pale brown; leafy shoots to 5(7) $\mathrm{cm}$ long and 2.5-3.5 $\mathrm{mm}$ wide, procumbent to erect; stem dark reddish brown, occasionally branched; leaves unequally bilobed, antical lobe not decurrent or slightly decurrent, ovate or ovate-orbicular, 0.9 $\mathrm{mm}$ long, $0.7 \mathrm{~mm}$ wide, apex rounded to obtuse, entire to strongly ciliate-dentate at base, postical lobe ovate or ovate-lingulate with slightly curved, winged keel, $1.7 \mathrm{~mm}$ long, $0.9 \mathrm{~mm}$ wide, decurrent, apex usually broadly rounded, margins dentate or dentate-serrate, teeth 1-3 cells long; leaf cells in middle of postical lobe 15-20 $\mu \mathrm{m}$ wide; oil-bodies 2-4 per cell; gemmae abundant, in green clusters, ovate to ellipsoid, 1-2 celled, thick-walled, 12-20 $\mu \mathrm{m}$ long (Fig. 1 and Fig. 2). Sporophytes unknown in Turkey.

Specimens examined: Turkey, north-west Anatolia. Sakarya: Akyazı district, on soil, alt. ca $223 \mathrm{~m}$, (40³9'37.56"N 30³8'42.99"E), 08 Nov 2011, herbarium no T.E. 1702 and R.K.1741 (Herbarium of Niğde University and special collections of EZER \& KARA (Niğde) (Fig. 1 and Fig. 2).

According to literature the species is dioecious; male bracts are in 2-8 pairs, bases often weakly inflated; female bracts are similar to and slightly larger than leaves; perianths to $2.5 \times 3.5 \mathrm{~mm}$, mouth laciniate with apical cilia 8(12) cells long, mouth sometimes gemmiferous; sporophytes are frequent in March to July; spores 12-16 $\mu \mathrm{m}$ (Smith, 1990; Paton, 1999; Casas et al., 2009).

$S$. nemorea and S. umbrosa are similar species to $S$. gracilis. Pale brownish-green colour is characteristic for $S$. gracilis but $S$. nemorea is green or dull green, rarely reddish or brownish. S. gracilis has gemmae in greenish clusters, whereas S. nemorea has gemmae in brownish clusters. While gemmae of $S$. gracilis are 1-2 celled and thick-walled, gemmae of $S$. nemorea are unicellular and thin-walled. The smallest forms of $S$. gracilis somewhat resemble $S$. umbrosa but $S$. umbrosa is pale or brownish green and has very pointed lobes, and shoot 


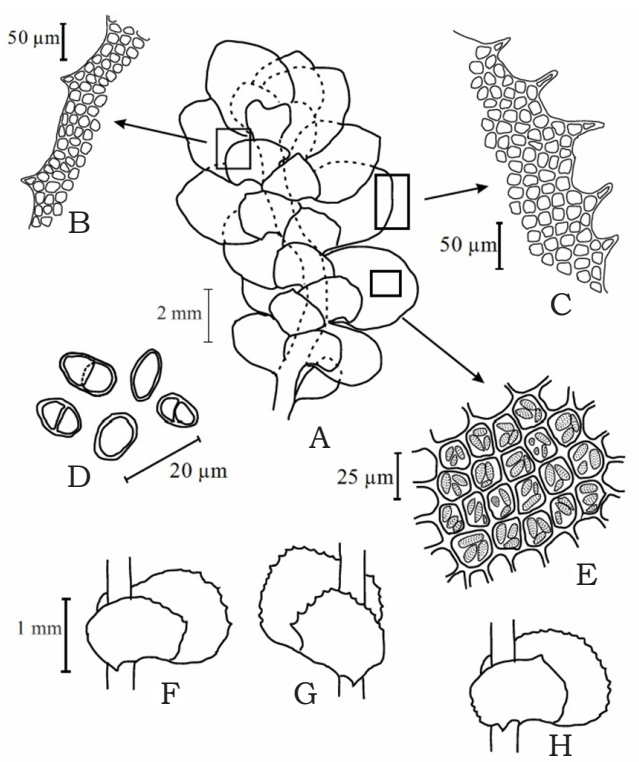

Fig. 1. Scapania gracilis. A - sterile shoot, antical view; B - leaf margin of antical lobe; $\mathrm{C}$ - leaf margin of postical lobe; D - gemmae; $\mathrm{E}$ - cells from middle of postical lobe; F, G, H - leaves.

tips deflexed. Also, thin-walled red gemmae are diagnostic of $S$. umbrosa.

Ecology and distribution.

Scapania gracilis Lindb. is acidophyt-subneutrophytic [pH 4.1-4.8; 5.7-7.0 $(-7,5)]$, hygrophytmesophytic, sciophytic-photophytic. The taxon preferantially grows on rocks and tree trunks, scree, ravines, on heaths and moorland, cliffs, occasionally on rotting logs and peat, calcifuge. (Smith, 1990; Paton, 1999). It is one of the characteristic species of the alliance ScapanioDicranetum scottiani (Dierssen, 2001) and the association Scapanio gracilis-Dicranetum scottiani Zippel 1998 (Kürschner et al., 2007).

In Turkey Scapania gracilis was collected on soil surface from Akyazı district. It was found together with the moss species Leucobryum juniperoideum (Brid.) Müll.Hal., Dicranum scottianum Turner ex R.R.Scott, Hypnum cupressiforme Hedw. and Atrichum angustatum (Brid.) Bruch \& Schimp., and the liverwort species Calypogeia fissa (L.) Raddi and Cephalozia bicuspidata (L.) Dumort.

Scapania gracilis is distributed in Portugal, Germany, Spain, France, Netherlands, Den-
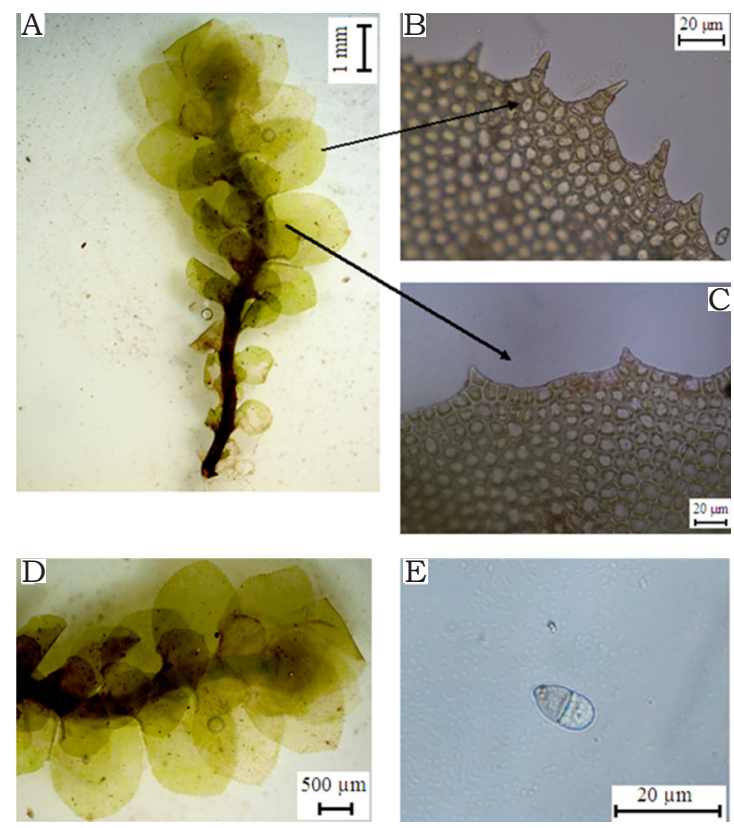

Fig. 2. Scapania gracilis. A - wet habit, antical view; $\mathrm{B}$ - leaf margin of postical lobe; C - leaf margin of antical lobe; D - apex of leafy shoot, antical view; E-gemma.

mark, Norway, Sweden, Faroe Islands, British Isles and Ireland, Macaronesia, Corsica, Italy, Greece, Romania and Morocco (Sotiaux et al., 1998).

\section{ACKNOWLEDGEMENTS}

We are indebted to the Scientific and Technological Research Council of Turkey TUBITAK (Project Number: 111T359) for support equipments to take photographs.

\section{REFERENCES}

Ben-Rong, Z., Tong, C. \& Shui-Liang, G. 2007. Comparison and assesment of three East-Asian species of the genus Scapania (Hepaticae: Scapaniaceae). Acta Phytotaxonomica Sinica 45 (5): 742-750. http://dx.doi.org/10.1360/aps06028

Casas, C., Brugués, M., Cros, R.M., Sérgio, C. \& Infante, M. 2009. Handbook of Liverworts and Hornworts of the Iberian Peninsula and the Balearic Islands. Illustrated Keys to the Genera and Species. Institut d'Estudis Catalans Barcelona. $177 \mathrm{pp}$. 
Dierssen, K. 2001. Distribution, ecological amplitude and pytosociological characterization of European bryophytes. Bryophytorum Bibliotheca 56: 1-289.

Kürschner, H. \& Erdağ, A. 2005. Bryophytes of Turkey: an annotated reference list of the species with synonyms from the recent literature and an annotated list of Turkish bryological literature. Turkish Journal of Botany 29: 95-154.

Kürschner, H., Stech, M., Fontinha, S., Sim-Sim, M. \& Frey, W. 2007. Epiphytic bryophyte communities of the Madeiran laurel and ericaceous forests - a phytosociological analysis. Nova Hedwigia 84(34): 333-362. http://dx.doi.org/10.1127/00295035/2007/0084-0333
Ozenoğlu Kiremit, H. \& Keçeli, T. 2009. An Annotated Check-list of the Hepaticae and Anthocerotae of Turkey. Cryptogamie Bryologie 30(3): 343-356.

Paton, J. 1999. The Liverworts Flora of the British Isles, Harley Books, Horkesley, Colchester, Essex CO6 4 AH, England. 626 p.

Smith, A. J. E. 1990. The Liverworts of Britain and Ireland, London, Cambridge University Press. 362 p.

Sotiaux, A., Sotiaux, O. \& Sotiaux, M. 1998. Scapania gracilis (Hepaticae) dans le département des Ardennes (France), nouveau pour le massif Ardennais. Belgian Journal of Botany 130(2): 131-134. 
120 Folia Cryptog. Estonica 